Ю.В. КЛІПА, Н.М. РІДЕЙ, Н.М. ТИТОВА, Д.Г. ПАВЛЕНКО, В.І. ТИМОШЕНКО

\title{
ОРГАНІЗАЦІЯ УПРАВЛІННЯ ПРОЦЕСОМ ПРОФЕСІЙНОЇ ПІДГОТОВКИ ЕКОНОМІСТІВ
}

\author{
(C) Кліпа Ю.В., 2019 \\ https://orcid.org/0000-0002-1210-1170 \\ (C) Рідей Н.М., 2019 \\ https://orcid.org/0000-0002-5553-059X \\ (C) Титова Н.М., 2019 \\ https://orcid.org/0000-0002-9415-4427 \\ (С) Павленко Д.Г., 2019 \\ https://orcid.org/0000-0002-1310-738X \\ (C) Тимошенко B.I., 2019 \\ https://orcid.org/0000-0001-6379-0204 \\ http://doi.org/10.34142/2312-2471.2019.62.10
}

У роботі розкрито архітектоніку та методику організації освітньонаукового процесу професійної підготовки фахівців-економістів банківської сфери з компетентностями для підприємництва. Сформульовано дефініції «професійна підготовка економістів», «підприємницька діяльність»; підібрано кваліфікації фахівців та професіоналів економістів банківської справи $з$ компетентностями для підприємницької діяльності, визначено можливості їх реалізачї у професійних середовищах за видами економічної діяльності. Визначено організаційно-педагогічні умови сочуіально-економічного спрямування, які орієнтовані на гарантування економічної безпеки на рівнях та y типах забезпечення. Досліджено сочіально-економічне замовлення попиту сфер працевлаштування на фахівців банківської справи (за сферами прачевлаштування) у галузях знань 01 Освіта/Педагогіка, 05 Сочіальні та поведінкові науки, 07 Управління та адміністрування за спеціальностями 015 Професійна освіта (Економіка), 051 Економіка та 072 Фінанси, економістів (за сферами працевлаштування) у галузях знань 01 Освіта/Педагогіка, 05 Соціальні та поведінкові науки, 07 Управління та адміністрування за спеціальностями 015 Професійна освіта (Економіка), 051 Економіка та 072 Фінанси. Запропоновано наповнення змістовно-методичної складової організації прочесу професійної підготовки майбутніх економістів, орієнтованої на гарантування національної економічної безпеки, галузевої за видами економічної діяльності та інституційної організачії для забезпечення розвитку підприємництва, а саме: розкрито змістовне наповнення освітньометодичного модуля «Економічної безпеки держави», функціональної складової «Економічної безпеки підприємства», суспільно-семантичної компоненти «Соціально-економічної безпеки» та інтегрованої синергетики иүільового змісту підготовки у сфері «Банківської справи». 
Ключові слова: професійна підготовка, фахівиі-економісти, види економічної діяльності, методика, академічний сервіс, соиіально-економічна безпека, банківська справа.

\section{Klipa Yu., Ridei N., Tytova N., Pavlenko D., Tymoshenko V. Management Organization in the Process of Economists' Professional Training}

The architectonics and methodology applied in organizing the educational and research work in economists' professional training for the banking sector, with competencies required for entrepreneurial activities, have been revealed. The definitions "professional training for economists", "entrepreneurship" have been formulated, specialists' qualifications and future professionals of banking economists with competencies for entrepreneurial activity have been selected, and the opportunities for implementation of expertise in professional environments have been identified by type of economic activity. The organizational and pedagogical conditions of socio-economic nature designed to ensure economic security have been determined, by level and type of specialty (with employment fields) in the fields of knowledge 01 Education / Pedagogy, 05 Social and behavioral sciences, 07 Management and administration by specialties 015 Vocational education (Economics), 051 Economics and 072 Finance, economists (with knowledge fields) in the fields of knowledge 01 Education / Pedagogy, 05 Social and behavioral sciences, 07 Management and administration by specialties 015 Vocational education (Economics), 051 Economics and 072 Finance. The socio-economic demand for banking specialists in areas of employment has been explored, the composition of the content and methodological component in organizing the process of professional training has been suggested as being intended to ensure national economic security, industry-specific security by type of economic activity, and institutional security to provide for development of entrepreneurship, namely, the content of the educational and methodological module "Economic security of the state", the functional component of "Economic security of the enterprise", the socio-semantic component of "Socio-economic security" and integrated synergetics of the target content of training in "Banking".

Key words: professional training, economists, types of economic activity, methodology, academic services, socio-economic security, banking.

Постановка проблеми. Дослідження фундаментальних аспектів методології організації системного управління процесу професійної підготовки фахівців у сфері економіки спрямоване на гарантування безпеки в межах банківського обслуговування за заздалегідь визначеними параметрами безпеки.

Розкрито архітектоніку організації професійної підготовки майбутніх економістів банківської справи 3 компетентностями підприємницької діяльності. «Професійна підготовка майбутніх економістів банківської справи для підприємницької діяльності» на нашу думку передбачає: здобуття кваліфікації фінансиста, бухгалтера, фахівця в сфері страхування, 
підприємництва, торгівлі та біржової діяльності системи державних або кооперативних банків у напрямах галузей знань 01 Освіта/Педагогіка, 05 Соціальні та поведінкові науки, 07 Управління та адміністрування; процес та результат професійного становлення та розвитку особистості 3 ноосферними, квалітологічними компетентностями підприємницького сервісу за видами економічної діяльності та бізнесу; форм організації освітньо-наукового процесу профільних 3ВО з удосконаленням професійної майстерності в функціональноцільових середовищах адаптації та саморозвитку професійної зайнятості.

Обгрунтовано у ході інституційного аналізу структурно-логічної будови соціально-економічного замовлення на підготовку майбутніх економістів банківської справи для підприємницької діяльності та візуалізовано схему основних замовників на фахівців за сферами їх працевлаштування.

Аналіз останніх досліджень і публікацій. Науково-теоретичним підгрунтям для дослідження стратегем економіки знань професійної підготовки майбутніх фахівців і гармонізації освітньо-наукового процесу забезпечення конкурентоспроможності висококваліфікованих фахівців зі економічної безпеки вважать, відповідно в ланцюгу викладення Д. Белла, М. Кастельса, Д. Куа, Р. Кроуфорда, Т. Сакайї, Дж. Ходжсона, А. Гальчинського, В. Гейця, А. Кінаха та В. Семиноженко; застосування методів економічного управління системами об’єктів управління - С. Будаговською, О. Кілієвичем, М. Павловським, О.Падалка; механізмів економічної безпеки - О. Бєляєва, М. Диби, В. Кириленко[1].

Аналіз психолого-педагогічної літератури свідчить, що наукові проблеми професійної підготовки майбутніх економістів для підприємницької діяльності грунтуються на положеннях i висновках наступних концепцій: концепції професійної підготовки (А. Алексюк, Н. Дем'яненко, О. Васюк, В. Свдокимов, В. Козаков, Т. Крилова, В. Кузь, В. Лозовецька, Л. Нічуговська, Н. Ничкало, В. Олійник, П. Підкасистий, О. Романовський, О. Ярошенко [2]), економікопедагогічних концепцій модернізації освітнього процесу викладання економічних дисциплін (Л. Коновалова), аналіз чинників економічної соціалізації особистості для професійного становлення (Н. Левицька) та інших учених [3]. Дослідженню проблеми формування професіоналів, які інноваційно вирішують завдання присвячені роботи у аспектах: методологічні засади сучасної філософії освіти (І. Зязюн, В.Кремень); теорія неперервної професійної освіти (С. Гончаренко, Р. Гуревич, А.Гуржій, М. Корець, В. Поліщук [4]).

Виділення невирішених раніше частин. Проте недостатньо дослідженими є особливості методики організації освітньо-наукового процесу професійної підготовки, умови соціо-економічного спрямування.

Мета дослідження полягає у розкритті особливостей архітектоніки та методики організації освітньо-наукового процесу професійної підготовки. У роботі виявлені організаційно-педагогічних умови соціо-економічного спрямування у сприятливому середовищі інтеграції освіти, науки та інноватики для реалізації академічного потенціалу ЗВО у формуванні фахових компетентностей для підприємницької діяльності майбутніх економістів, 
подано вивчення соціально-економічного попиту сфер працевлаштування майбутніх економістів для удосконалення змістовно-методичного контенту організації процесу професійної підготовки на засадах економічної безпеки держави, суспільства, підприємства та працівників банківської справи для забезпечення підприємницької діяльності.

Для розв’язання поставленої мети використовувалися методи: загальні mеоретичні - теоретико-методологічний аналіз наукової літератури з проблем структурування освітньо-наукового процесу професійної підготовки; систематизація теоретичних даних практично-корисного досвіду для встановлення особливостей підготовки; спеціальні теоретичні методи аналізу - аксіологічний та інституційний; системний, портфельний та причиннонаслідковий; проблемний; прогностичний та аналіз ефективності.

Виклад основного матеріалу. Процес професійної підготовки майбутніх економістів банківської справи для підприємницької діяльності у дуальному феномені (компонентних цілей) спрямовано на досягнення мети отримання системних кваліфікацій та забезпечення відповідності професійним середовищам працевлаштування згідно семантики видів економічної діяльності, які систематизовано за логікою викладення та узгоджено 3 нормативними документами державного регулювання професійної зайнятості, як це і представлено у таблиці 1.

Система підготовки у сприятливому середовищі інтеграції освіти, науки та інноватики забезпечує професійний потенціал висококваліфікованих економістів згідно кон'юнктури ринку праці, який за цільовою орієнтацією професійної підготовки реалізується у компонентних цілях: здобуття кваліфікацій фахівців та професіоналів економістів банківської справи 3 компетентностями для підприємницької діяльності (ДК 003: 2010 Класифікатор професій - 2020) та ефективність освітньо-наукового процесу, досягнення релевантності фахового навчання, адаптації, становлення та розвитку особистості зі сталими компетентностями управління якістю та безпеки життя, ноосферним світоглядом, квалітології банківського сервісу підприємництва за видами економічної діяльності (КВЕД ДК 009:2010).

Методика організації освітньо-наукового процесу професійної підготовки фахівців-економістів банківської сфери обслуговування підприємницької діяльності обгрунтована у триадному феномені і представлена у таблиці 2.

Визначено, що система підготовки включає мотиваційну (відображає ставлення особистості до професійної діяльності), когнітивну (включає теоретичні і технологічні знання), професійно-діяльнісну (включає уміння, навички за результатами сформованих знань) складові структури системи підготовки 3 частин - теоретичної та методико-технологічної і охоплює наступні елементи: міжпредметні зв’язки, складові компетентності фахівця 


\section{ЦІЛЬОВА ОРІЕНТАЦІЯ ПРОФЕСІЙНОЇ ПІДГОТОВКИ МАЙБУТНІХ ЕКОНОМІСТІВ БАНКІВСЬКОЇ СПРАВИ}

Таблиия 1

Компонентні цілі результативності професійної підготовки

Компонентна иุіль 1 - здобуття кваліфікацій фахівиів та професіоналів економістів

банківської справи з компетентностями для підприємницької діяльності

ДК 003: 2010 Класифікатор професій - 2020

Компонентна изіль 2 - процес та результат професійного навчання, адаптаиії, становлення та розвитку особистості зі сталими компетентностями управління якістю та безпеки життя, ноосферним світоглядом, квалітологї банківського сервісу підпиємнищтва за видами економічної діяльності - КВЕД ДК 009:2010.

фінансиста та фахівця в сфері страхування, із заставних та фінансових операцій, торгівлі, біржової та підприємницької діяльності (341 фахівці в галузі фінансів та торгівлі: 3411-3413, 3419 - дилери (біржов торговці за свій рахунок) та брокери (посередники), страхові агенти, агенти з торгівлі майном та інші фахівці); фахівці 3 комерційного обслуговування та бухгалтери (342 агенти 3 комерційного обслуговування та торговельні брокери: 3421, 3423, 3429, 3433, 3436 - брокери (посередники) з купівлі-продажу товарів, агенти із зайнятості й трудових контрактів, агенти з комерційних послуг та торговельні брокери, бухгалтери та касириексперти, 3436 - помічники керівників підприємств, установ та організацій (виробничих та інших основних підрозділів, малих підприємств без апарату управління)), а також технічні службовці (411 секретарі та службовці, що виконують операції за допомогою клавіатури: 4111-4115 - стенографісти та друкарки, оператори машин для оброблення текстів та лічильних і подібні професії зі збору даних, секретарі; 412 службовці, зайняті з цифровими даними - 4121, 4122 реєстратори бухгалтерських даних, статистикиобліковці та конторські службовці, що займаються фінансовими операціями; 421 касири, касири в банках та білетери - 4211-4215 касири та білетери, інкасатори банків, букмекери та круп'є (банківники), лихварі (особи, що позичають гроші в заставу або в борг), контролери у банку, касири-оператори автоматизованої системи оброблення банкнот, касири (в банку), операціоністи, збирачі податків) у галузі знань - 05 Соціальні та поведінкові науки зі спеціальності 051Економіка, 07 Управління та адміністрування зі спеціальності 072 Фінанси, банківська справа та страхування; фахівців у галузі освіти (334 інші фахівці в галузі освіти: 3340 педагоги професійного навчання, інструктор та майстер виробничого навчання, методист 3 професійної реабілітації) у галузі знань 01 Освіта/Педагогіка зі спеціальності 015Професійна освіта (Економіка) для кадрового забезпечення банківської сфери обслуговування у державних та кооперативних банків; фінансова та страхова діяльність: 64-66 надання фінансових послуг, крім страхування та пенсійного забезпечення, страхування, перестрахування та недержавне пенсійне забезпечення (крім обов'язкового соціального страхування), допоміжна діяльність у сферах фінансових послуг і страхування; операції з нерухомим майном 68) бізнесу та підприємництва у галузях сільського, рибного та лісового господарства (01-03), переробної промисловості (10-33), у сфері професійної, наукової та технічної діяльності (69-75), освіти (85), домашнього господарювання (97-98); форм організації освітньо-наукового процесу профільних ЗВО 3 удосконаленням професійної майстерності в функціонально-цільових середовищах адаптації та саморозвитку професійної зайнятості. 
(предмет діяльності, функції, уміння), активізацію знань засобами психологічних, методичних та управлінських механізмів, активізацію діяльності, до якої входять мотив, мета, засоби та результати, компоненти - мотиваційний, когнітивний, професійно-педагогічний; рівні підготовки: теоретичні та практичні пояснювальний, діагностичний, експериментальний, інформаційний, проективний, рефлексивний, діяльнісний; авторські спецкурси.

Таблиця 2

МЕТОДИКА ОРГАНІЗАЦЇ̈ ОСВІТНЬО-НАУКОВОГО ПРОЦЕСУ

\begin{tabular}{|c|c|}
\hline $\begin{array}{l}\text { No } \\
\text { I/I }\end{array}$ & $\begin{array}{c}\text { Найменування тріадних компонентів } \\
\text { методики організації освітньо-наукового процесу }\end{array}$ \\
\hline 1. & Система синхронізованих науково-обтрунтов \\
\hline & 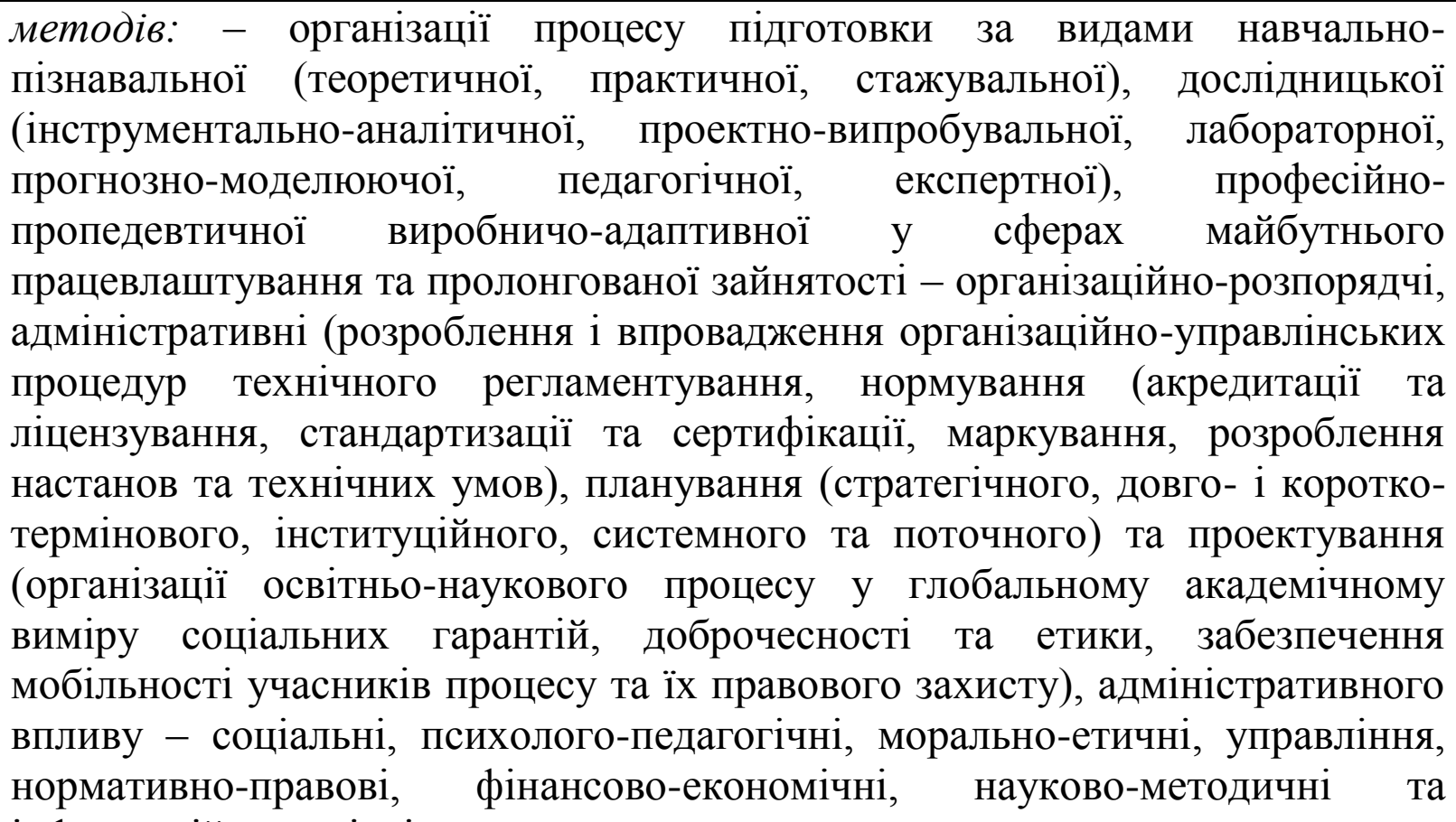 \\
\hline
\end{tabular}

- організаційно-стабілізуючі - інституційно-організаційні, функціональні цільового призначення, субординаційно-координаційні посадові;

- пізнавально-діяльнісні (мотиваційного стимулювання, полігонні лабораторні інтерактивно-ситуаційні, джерельного базису інформації - бібліотечних, науково-метричних, дисциплінарних та курсових, довідкових та енциклопедичних;

- логіки наукового пізнання та засвоєння новітніх наукових знань та методик дослідження у сучасних методологічних напрямах;

- моніторингу, нагляду, контролю та самоконтролю релевантності навчальних досягнень; бінарні, матричні комбіновані навчальні);

- наукові методи аналізу (аксіологічний, інституційний, компаративний, кластерний системний, SWOT, портфельний, причиннонаслідковий, по критеріям «затрати-зиски», кейс-метод, проблемний, 
Збірник наукових праць «Педагогіка та психологія». - Харків, 2019. - Вип. 62.

\begin{tabular}{|c|c|}
\hline $\begin{array}{l}\text { № } \\
\text { II/II }\end{array}$ & $\begin{array}{c}\text { Найменування тріадних компонентів } \\
\text { методики організації освітньо-наукового процесу }\end{array}$ \\
\hline & ефективності, прогностичний); \\
\hline 1.2 & $\begin{array}{l}\text { засобів матеріально-технічного та інформаційно-телекомунікаційного } \\
\text { аналітичного забезпечення (графічно-демонстраційні на різних } \\
\text { інформаційно-комунікаційних носіях, телекомунікаційні, інтерактивні, } \\
\text { технічні, проектні мультимедійні, лабораторно-інструментальні (АСК, IC } \\
\text { та ІБ), обліку та інвентаризації та систематизації оперативних } \\
\text { інформаційних даних, науково-методичні та нормативно- та законодавчо- } \\
\text { регулятивні), розроблення інформаційно-аналітичних систем консалтингу } \\
\text { та дорадництва для підприємницької діяльності; }\end{array}$ \\
\hline 1.3 & $\begin{array}{l}\text { форм (за дидактичною метою - теоретичного, практичного, стажувального } \\
\text { інтегрованого освітньо-наукового процесу; за місцем дислокації - } \\
\text { навчально-виховні, науково-дослідні, } \\
\text { інституційно-стажувальні; за комплектацією здобувачів освітніх та } \\
\text { освітньо-наукових портативних програм навчання (у групах) - } \\
\text { індивідуальні персоніфіковані, комплексні бригадні (або у ланках), в малих } \\
\text { та експертно-аналітичних (громадських експертів та інспекторів) групах, } \\
\text { творчо-лабораторні, гурткові та факультативні, проблемні, дискусійних } \\
\text { клубів). }\end{array}$ \\
\hline 2 & $\begin{array}{l}\text { Спосіб організаиії процесу професійної підготовки здобувачів освіти } \\
\text { для галузей економіки }\end{array}$ \\
\hline 2.1 & $\begin{array}{l}\text { за видами економічної діяльності, банківської справи та їх розвитку через } \\
\text { сервіс підприємництва; }\end{array}$ \\
\hline 2.2 & $\begin{array}{l}\text { обумовлений закономірностями управління якістю та безпекою в ЗВО на } \\
\text { засадах сталості (синергізму та збалансованості цілей, завдань у досягненні } \\
\text { мети теоретичного, практичного навчання і дослідництва, інституційно- } \\
\text { професійного стажування щодо формування у фахівців економістів } \\
\text { готовності забезпечувати стратегічне управління соціально-економічним } \\
\text { розвитком суспільства з дотриманням національних та міжнародних вимог } \\
\text { економічної безпеки; застосування передового практично-корисного } \\
\text { досвіду у співпраці } 3 \text { працедавцями, представника-ми громадськості, } \\
\text { державного регулювання, режимних служб безпеки та інших зацікавлених } \\
\text { сторін; релевантності майбутньої професійної діяльності для організації } \\
\text { раціонального природокористування, управління збалансованим розвитком } \\
\text { суб’єктів підприємництва та банківського обслуговування); }\end{array}$ \\
\hline 2.3 & $\begin{array}{l}\text { гармонізації структури системи організації на принципах (дотичних у } \\
\text { дослідженні - інформаційно-діяльнісний, наукового пізнання, управління } \\
\text { якістю, процесний, раціональної організації управління, розробки програм; } \\
\text { потенційних - планування та прийняття управлінських рішень, суспільного } \\
\text { управління, організації адміністративного менеджменту); }\end{array}$ \\
\hline 2.4 & $\begin{array}{l}\text { यілісності методологічного змісту процеесу формування (у функціях } \\
\text { призначення: } \quad \text { аксіологічно-мотиваційній, } \\
\begin{array}{l}\text { академічно-методологічній, } \\
\text { прогнозувально-моделювальній, }\end{array}\end{array}$ \\
\hline
\end{tabular}




\begin{tabular}{|c|c|}
\hline $\begin{array}{l}\text { № } \\
\text { II/II }\end{array}$ & $\begin{array}{c}\text { Найменування тріадних компонентів } \\
\text { методики організації освітньо-наукового процесу }\end{array}$ \\
\hline & $\begin{array}{l}\text { ідентифікаційно-закріплювальній, моніторинго-коригувальній) у майбутніх } \\
\text { економістів банківської справи } 3 \text { компетентністю для підприємницької } \\
\text { діяльності. }\end{array}$ \\
\hline 3 & $\begin{array}{l}\text { академічний сервіс формування сприятливого середовищу інтеграиії } \\
\text { освіти, науки й інноватики шляхом забезпечення ефективності } \\
\text { організаційно-педагогічних умов }\end{array}$ \\
\hline 3.1 & $\begin{array}{l}\text { науково-методичне, організаційно-управлінське забезпечення; матеріально- } \\
\text { технічний, інформаційно-телекомунікаційний потенціал мобільності та } \\
\text { соціального виміру; якість складових академічної спадщини соціально- } \\
\text { економічного спрямування професійної підготовки висококваліфікованих } \\
\text { економістів з компетентностями для підприємницької діяльності. }\end{array}$ \\
\hline
\end{tabular}

Структура підготовки цілісно охоплює наскрізний процес підготовки студента, якому властиві системна єдність та наступність підструктурних частин, наявність інтегративних зв'язків між ними, початок та кінцевий результат ефективності діяльності ㄲi архітектоніки у взаєминах внутрішньої синхронізації. Полікомпетенційна підготовка економістів здійснюється на засадах теорії та методики професійної освіти 3 урахуванням компетентнісної підготовки; $\epsilon$ інтегральною підготовкою в єдності економічних та педагогічних наук i здійснюється 3 урахуванням інтересів національної та європейської освітніх систем на засадах стратегії соціо-економічного розвитку та гарантій економічної безпеки.

Соціально-економічне замовлення суспільства на підготовку майбутніх економістів (за сферами працевлаштування) у галузях знань 01 Освіта/Педагогіка, 05 Соціальні та поведінкові науки, 07 Управління та адміністрування за спеціальностями 015 Професійна освіта (Економіка), 051 Економіка та 072 Фінанси, банківська справа та страхування обумовлена суспільними запитами на задоволення висококваліфікованими кадрами (фахівців-економістів банківської справи 3 компетентностями для підприємницької діяльності), що обгрунтовано в державній політиці національної безпеки.

Основними відомчими та інституційними координаторами/замовниками на підготовку майбутніх економістів $є$ відомства України: Міністерство освіти i науки (директорати: науки та інновацій - головне управління із реалізації політик у сфері науки та інновацій; професійної освіти- головне управління професійної освіти; стратегічного планування та європейської інтеграції; вищої освіти і освіти дорослих - головне управління вищої освіти; департаменти: фінансування державних і загальнодержавних видатків, управління бухгалтерського обліку та звітності; забезпечення документообігу, контролю та інформаційних технологій).

До них додаються Міністерство захисту довкілля та природних ресурсів (державні агентства: лісових ресурсів; рибного господарства; з управління зоною відчуження, водних ресурсів; державна екологічна інспекція; державна служба геології та надр); Міністерство охорони здоров'я (національна служба здоров'я, 
державна служба з лікарських засобів та контролю за наркотиками); Міністерство інфраструктури (державні служби з: транспорту, безпеки комунікацій; державне агентство інфраструктурних проектів); Міністерство соціальної політики (державні служби: соціальна, з питань праці; пенсійний фонд); Міністерство внутрішніх справ (національна поліція, державні служби: адміністрація прикордонної, міграційна та 3 надзвичайних ситуацій).

До цього списку додаються Міністерство закордонних справ; Міністерство юстиції (державна архівна служба); Міністерство фінансів (державні служби: митна, податкова, аудиторська, казначейська, фіскальна, фінансового моніторингу; агентство з управління державним боргом); Міністерство цифрової трансформації (адміністрація державної служби спеціального зв'язку та захисту інформації); академічні інституції України: Національна академія державного управління при Президентові, Національна академія наук, Національна академія педагогічних наук, Національна академія аграрних наук, Національна академія правових наук; національний координатор банківського забезпечення та обслуговування України: Національний банк.

Економісти банківської справи користуються попитом: за спеціальними напрямами професійної підготовки 3: системного аналізу якості економічної безпеки (профільні центри підготовки майбутніх економістів: державного управління безпекою, стратегічного управління соціально-економічним розвитком), прикладної економіки (профільні центри підготовки майбутніх економістів: біоекономіка та екологічний аудит, прикладна економіка, економіка туризму та рекреації), економічної безпеки та бізнес-аналітики (профільні центри підготовки майбутніх економістів: економіка інформаційних технологій та програмування, економіка підприємств, зовнішньо-економічна діяльність), соціальної економіки та фінансової безпеки (профільні центри підготовки майбутніх економістів: економіка кадрів, бізнес-економіка, банківська та страхова справа) для реалізації принципів економічної безпеки на рівнях (транскордонноміжнародному, державно-національному, регіонального адміністративнотериторіального, територіально-громадського, локально-інституційного).

За функціональним цільовим призначенням у сфері семантичного управління макроекономічною державною та зовнішньо економічною безпекою (економічною, охороною довкілля, природокористуванням у галузях економічної діяльності, економіки природокористування, модернізацією економічної освіти) через застосування загальних інструментів управління економічною безпекою (за групами критеріїв економічної безпеки та діагностики стану економічної безпеки, за критеріями оцінювання ефективності функціонування системи економічної безпеки); - за групами індикаторів встановлення стану економічної безпеки України (інвестиційна, соціальна, науково-технологічна, видів життєзабезпечення країни: продовольча, демографічна, енергетична, виробнича; фінансова за видами: бюджетна, ринку грошей та інфляції, валютна, боргова, страхового ринку, фондового ринку, банківська) через механізми економічної безпеки національного та регіонального значення (системний моніторинг якості; об'єктивність державної статистики; державне прогнозування та моделювання стану та розвитку систем; 
методологія оцінювання економічних загроз) у ефективній реалізації функцій професійної підготовки (суспільно-політичні, соціально-економічні, екологобезпечні організаційно-правові та нормативно-технологічні засади розвитку системи економічної безпеки; методологічна наукового пізнання «Економіки, заснованої на знаннях», «Суспільства знань»; транскордонна інтегративна міжнародна система економічної безпеки).

Методологічний зміст професійної підготовки майбутніх економістів банківської справи базується на національній політиці безпеки та ії економічної складової, ієрархічно забезпечується механізмами національного та регіонального рівня і представлено у таблиці 3.

Встановлено сутність поняття та сформульовано в авторському трактуванні «підприємницька діяльність» - автономне, інноваційне, системно-процесне підприємництво за власної ініціативи та 3 усвідомленням можливих ризиків i небезпек господарської економічної діяльності для досягнення соціальноекономічної стабільності професійного зростання, забезпечення добробуту через одержання матеріального зиску.

Висновки. Запропоновано методологічний зміст професійної підготовки майбутніх економістів банківської справи 3 компетентностями для підприємницької діяльності. Методологічний зміст професійної підготовки майбутніх економістів банківської справи 3 компетентностями для підприємницької діяльності включає: фундаментальні основи поняття економічної безпеки держави (національні економічні пріоритети, соціальноекономічного розвитку, економічна безпека в умовах глобалізації, оцінка рівнів безпеки держави, критерії та індикатори безпеки держави); внутрішні компоненти економічної безпеки України (види - енергетична та ресурсно-сировинна, науково-технологічна, інвестиційна, фінансова, продовольча, безпека потенціалу людського розвитку); зовнішньоекономічна безпека (види - експортна, імпортна, зовнішня безпека міжнародного капітал обігу та трудової міграції).

До цього додається модель інноваційного формування економічної безпеки державного розвитку (модернізація соціо-економічних систем, інформаційна безпека суб'єктів інноваційної діяльності); інституалізація умов формування економічної безпеки (інституційна архітектоніка соціально-економічного розвитку, інституціональні деструкти, правові гарантії впровадження концепції національної економічної безпеки України); безпека якості життя (види біосоціальна, екологічна, безпека життєдіяльності).

Суспільні запити на підготовку економістів у професійних середовищах працевлаштування за галузями знань 01 Освіта/Педагогіка, 05 Соціальні та поведінкові науки, 07 Управління та адміністрування зумовлені попитом відомчих, інституційних, корпоративних та приватних роботодавців на висококваліфікованих кадрів професійно-компетентних у напрямах економічних видів діяльності орієнтованих на банківський сервіс раціонально-безпечного обслуговування підприємницької діяльності, а також системи національної академї наук України та галузевих академій (включаючи НААНУ, НАПрН, НАПН), НАДУ і систему НБУ. 
Таблиия
ВСБКОї СПРАВИ

\begin{tabular}{|c|c|}
\hline $\begin{array}{c}\text { Найменування } \\
\text { складових }\end{array}$ & Змістове наповнення складових \\
\hline $\begin{array}{l}\text { стратегічна } \\
\text { складова } \\
\text { «Економічна } \\
\text { безпека держави» } \\
\text { (далі - ЕБД) [9] }\end{array}$ & 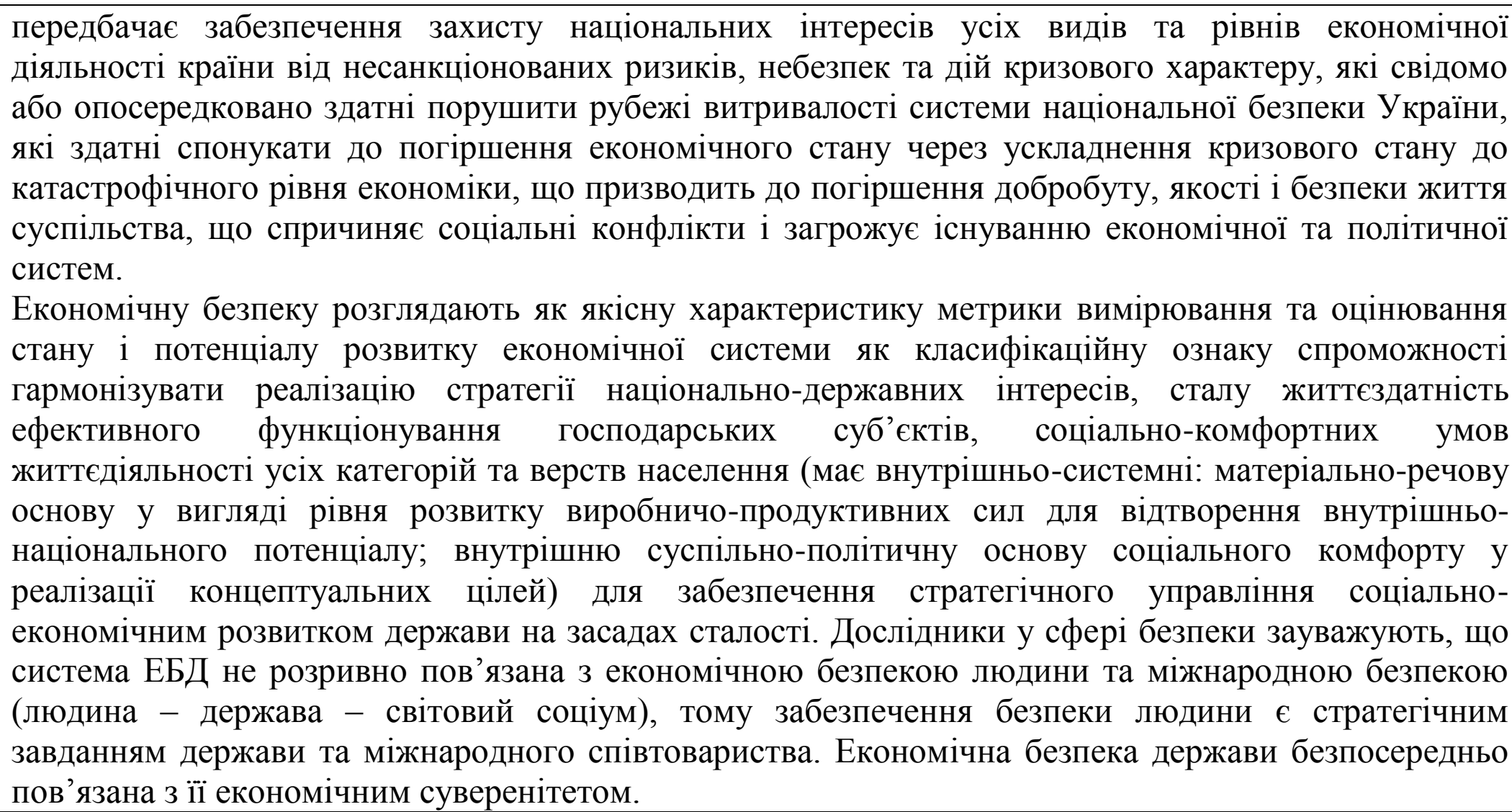 \\
\hline $\begin{array}{l}\text { функціональна } \\
\text { складова } \\
\text { «Економічної } \\
\text { безпеки }\end{array}$ & $\begin{array}{l}\text { включає основні проблемно-інтегровані компоненти: теоретичні основи економічної безпеки } \\
\text { підприємства (далі - ЕБП) (поняття, концепція, світовий досвід ЕБП); методологія системного } \\
\text { управління ЕБП (організація системного управління, стратегія інформаційно-аналітичне та } \\
\text { інноваційного забезпечення); методика метрики оцінювання ЕБП (складові ЕБД, моніторинг та }\end{array}$ \\
\hline
\end{tabular}




\begin{tabular}{|c|c|}
\hline $\begin{array}{l}\text { Найменування } \\
\text { складових }\end{array}$ & Змістове наповнення складових \\
\hline $\begin{array}{c}\text { підприсмства» } \\
{[10]}\end{array}$ & $\begin{array}{l}\text { вимірювання, підходи наукового пізнання, системного аналізу, конкретно-наукові методи } \\
\text { оцінювання економічної безпеки регіону, галузі та підприємства, технології моделювання стану } \\
\text { ЕБП); корпоративна економічна безпека підприємств-партнерів (нормативно-правове та технічне } \\
\text { регулювання корпоративного управління підприємствами та їх безпекою, чинники ризиків, загроз } \\
\text { та небезпек, діагностика ризиків та небезпек спільної співпраці); семантика антикризового } \\
\text { менеджменту інноваційних проектів підприємництва (принципи організації та управління ризиком, } \\
\text { цілями та результативністю інноваційних проектів підприємництва); загрози економічної безпеки } \\
\text { інноваційного підприємства (небезпеки внутрішнього та зовнішнього середовищ інноваційного } \\
\text { підприємства, «турбулентність» і «біфуркація» в розвитку на різних етапах та циклах } \\
\text { інноваційного проектування, інноваційна безпека); індикативний підхід до економічної безпеки } \\
\text { інноваційного підприємства (індикатори та структура безпеки - фінансово-економічної, } \\
\text { інформаційної, академічної та кадрової, науково-технологічної, ринкової, правової, екологічної, } \\
\text { інвестиційної, харчової, енергетичної, торгової, соціальної, демографічної та виробничої). }\end{array}$ \\
\hline $\begin{array}{c}\text { семантична } \\
\text { складова } \\
\text { «очіально- } \\
\text { економічна } \\
\text { безпека» (далі- } \\
\text { СЕБ) [11] }\end{array}$ & 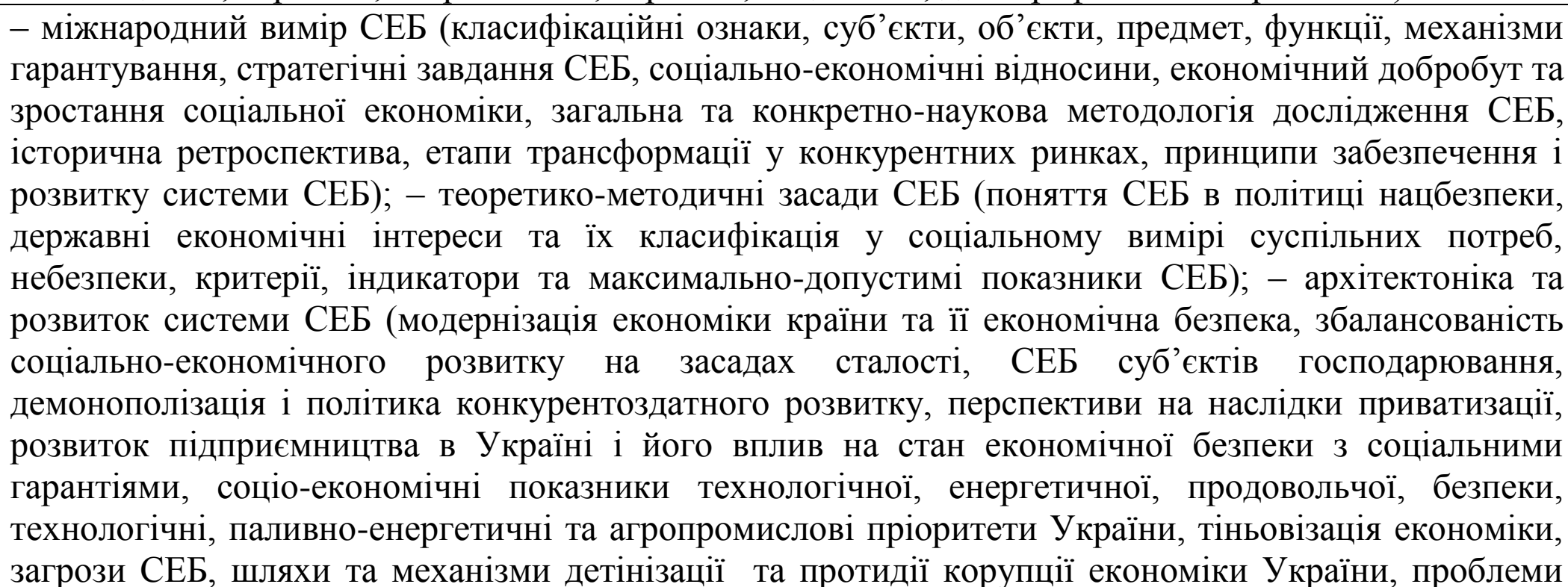 \\
\hline
\end{tabular}


Збірник наукових праць «Педагогіка та психологія». - Харків, 2019. - Вип. 62.

\begin{tabular}{|c|c|}
\hline $\begin{array}{c}\text { Найменування } \\
\text { складових }\end{array}$ & Змістове наповнення складових \\
\hline & 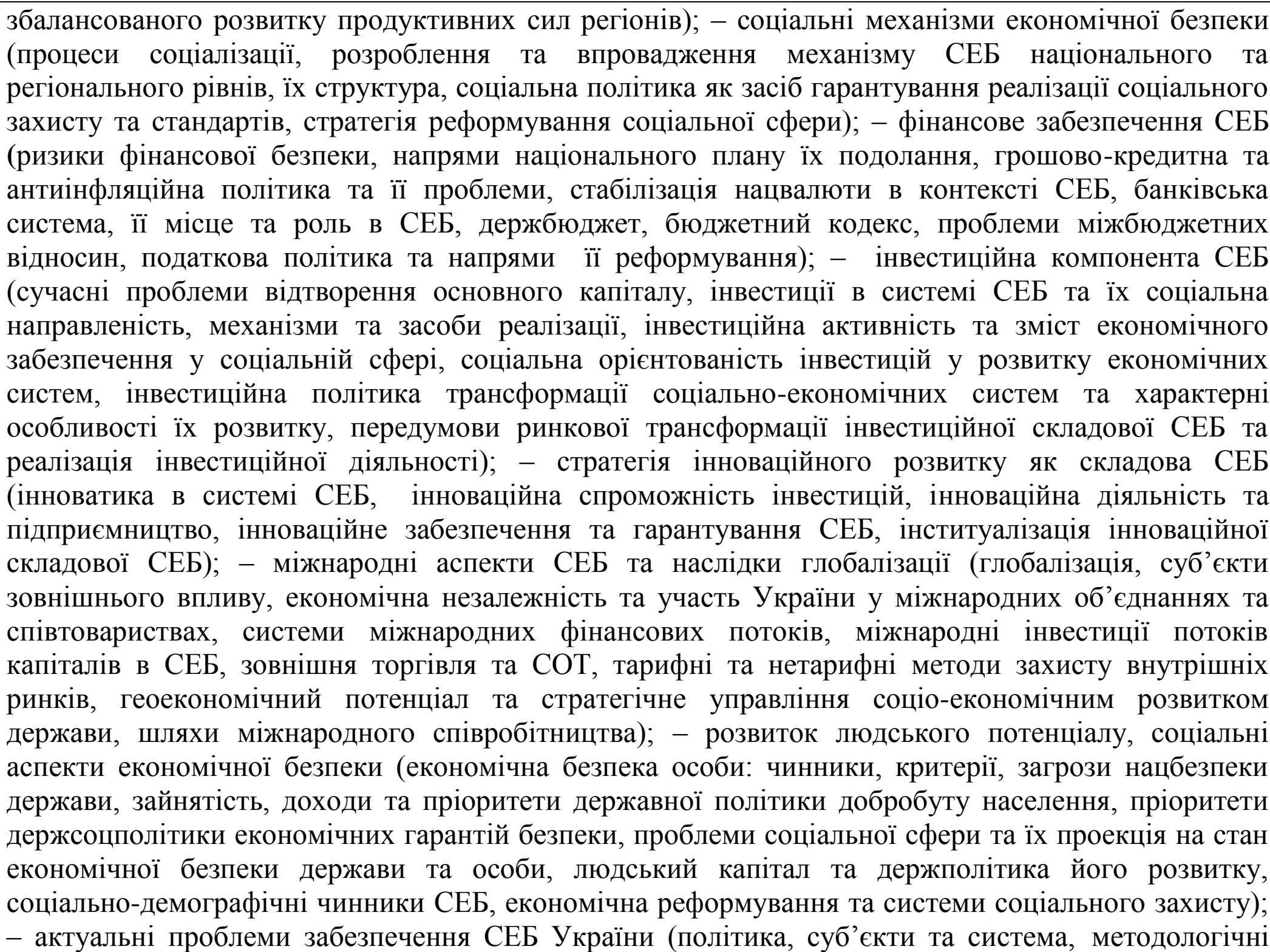 \\
\hline
\end{tabular}




\begin{tabular}{|c|c|}
\hline $\begin{array}{c}\text { Найменування } \\
\text { складових }\end{array}$ & Змістове наповнення складових \\
\hline & $\begin{array}{l}\text { засади механізмів забезпечення, мета і методи аналізу та моніторингу економічної безпеки країни, } \\
\text { правове та технічне регулювання, оптимізація системи держуправління, міжнародний досвід } \\
\text { гарантування та стратегія забезпечення СЕБ). }\end{array}$ \\
\hline $\begin{array}{l}\text { цільова складова } \\
\text { «Банківська } \\
\text { справа» [12] }\end{array}$ & $\begin{array}{l}\text { полягає у тематиці структурно-логічної будови забезпечення процесу підготовки: - правове } \\
\text { регулювання банківської діяльності України (види, суть, функції банківського обслуговування та } \\
\text { порядок регулювання в умовах ринкової економіки, поняття та характерні особливості } \\
\text { функціонування банківської системи, регламенти створення та реєстрації банків); - організація } \\
\text { управління банківської системи (структурно-організаційна будова та системне управління банком } \\
\text { або їх об'єднаннями, розвиток національної банківської сфери, зміст, класифікація операцій та } \\
\text { ліцензування права на банківське обслуговування); - банківські операції з формування власного } \\
\text { капітал обороту (ресурси, види та класифікація банківських активів, фінансова структура, функції } \\
\text { та порядок формування власного капіталу, технічне регулювання нормативів капіталу банківських } \\
\text { установ); банківські операції із залучення фінансових донорів (визначення потенційно можливих } \\
\text { залучених банківських ресурсів, депозитні операції комерційних банків, договірне врядування } \\
\text { операцій зі вкладами, фонд іх гарантування для фізичних осіб); - банківські операції із фінансових } \\
\text { займів (поняття та класифікація запозичених ресурсів, зміст та роль міжбанківського кредитування } \\
\text { для формування фондів запозичених ресурсів, види, регламенти забезпечення та реверсного } \\
\text { кредитування, характерні особливості емісії банком інституційних боргових зобов'язань); - } \\
\text { банківські операції обслуговування обороту платоспроможності (характеристика платіжного } \\
\text { обороту, кктегорія системи організації безготівкових розрахунків, регламенти } \\
\text { документозабезпечення, порядок відкриття, використання і закриття рахунків у банках, } \\
\text { особливості форм безготівкових розрахунків, розрахунки з - платіжними дорученнями, вимогами } \\
\text { та вимогами-дорученнями, з розрахунковими чеками, за акредитивами, під час врегулювання } \\
\text { взаємної заборгованості, засобами систем дистанційного обслуговування; необхідність, зміст, } \\
\text { класифікація і порядок здійснення міжбанківських розрахунків, міжбанківських розрахунків, } \\
\text { електронне врядування системи електронних платежів НБУ, відкриття та закриття } \\
\text { кореспондентських рахунків банків, моделі обслуговування консолідованого кореспондентського }\end{array}$ \\
\hline
\end{tabular}


Збірник наукових праць «Педагогіка та психологія». - Харків, 2019. - Вип. 62.

\begin{tabular}{|c|c|}
\hline $\begin{array}{c}\text { Найменування } \\
\text { складових }\end{array}$ & Змістове наповнення складових \\
\hline & 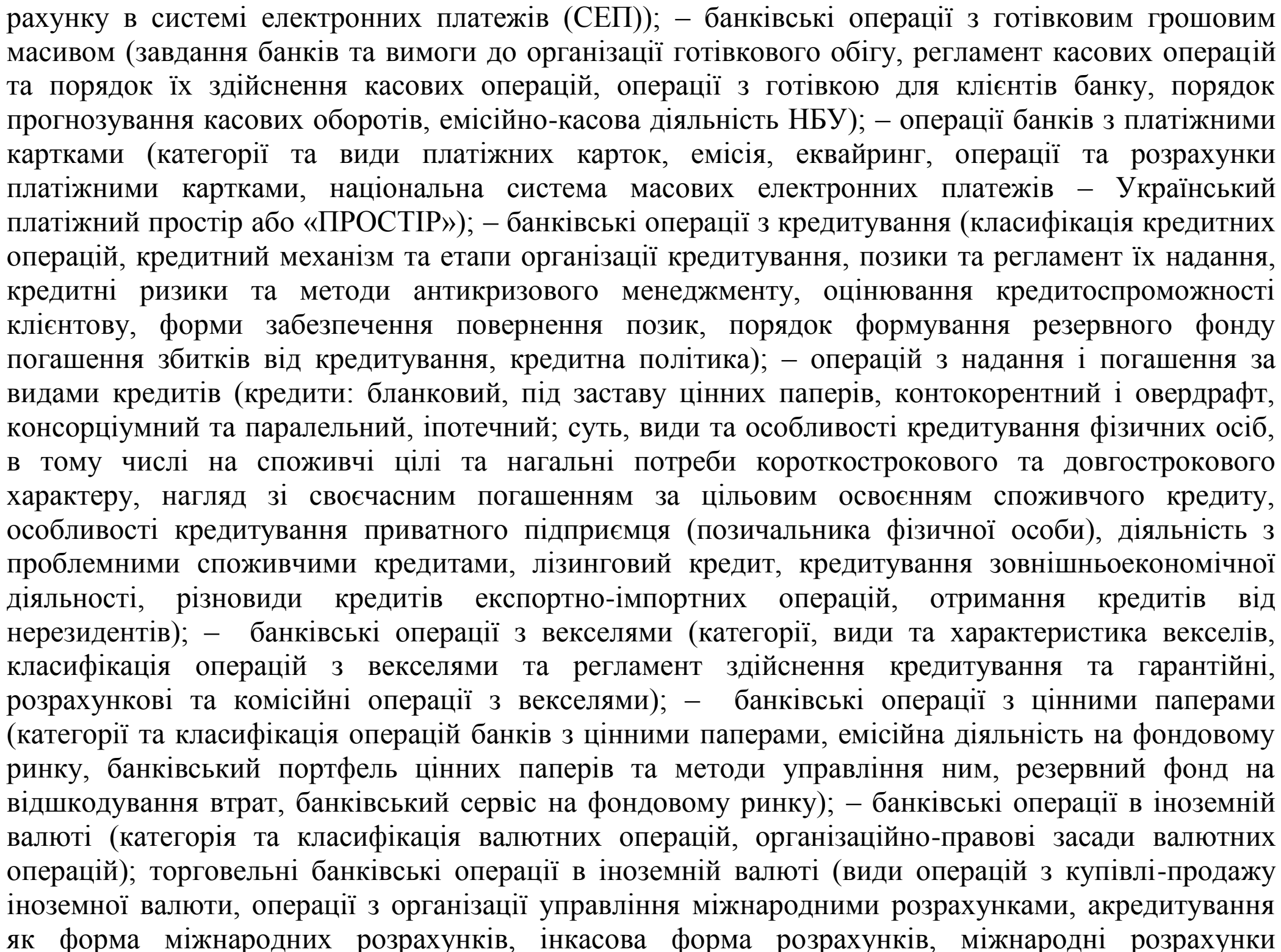 \\
\hline
\end{tabular}




\begin{tabular}{|l|l|}
\hline $\begin{array}{c}\text { Найменування } \\
\text { складових }\end{array}$ & \multicolumn{1}{|c|}{ Змістове наповнення складових } \\
\hline & $\begin{array}{l}\text { банківського переказу, нагляд за розрахунками за експортними, імпортними та міжнародними } \\
\text { лізинговими операціями, відкриття та ведення валютних рахунків кліснтів); - неторговельні } \\
\text { банківські операції в іноземній валюті (операції з готівковою інвалютою, з дорожніми чеками, } \\
\text { міжнародні перекази коштів фізичних осіб); міжбанківські операції в іноземній валюті (організація } \\
\text { торгівлі інвалютою на міжбанківському ринку, кореспондентських відносин з іноземними банками, } \\
\text { фундаментальний та технічний аналіз валютного ринку, управління валютним ризиком); } \\
\text { банківський сервіс 3 надання послуг (сутність та класифікація банківських послуг, гарантії та } \\
\text { порука, факторингові, трастові, посередницькі, консультаційні та інформаційні послуги, операції } \\
\text { банків з дорогоцінними металами); - банківські операції зі забезпечення фінансової стійкості } \\
\text { (чинники фінансової стійкості банку, фінансова звітність, методи оцінювання прибутковості та } \\
\text { управління ліквідністю банків, регулювання діяльності банків (в тому числі резервування) для } \\
\text { фінансової стійкості, нагляд та контроль за нею, режим фінансового оздоровлення банківської } \\
\text { діяльності). }\end{array}$ \\
\hline
\end{tabular}


Економісти банківської справи реалізуються у: спеціалізованих напрямах професійної підготовки, конкретизованих - системного аналізу якості складових економічної безпеки, семантики управління макроекономічною державною та зовнішньо-економічною безпекою, діагностики індикаторів визначення стану економічної безпеки держави, реалізацію механізму економічної безпеки національного та регіонального рівня через функціональну направленість професійної підготовки. Рекомендовано змістовне наповнення освітньо-методичного модуля «Економічної безпеки держави», функціональної складової «Економічної безпеки підприємства», суспільно-семантичної компоненти «Соціально-економічної безпеки» та інтегрованої синергетики цільового змісту підготовки у сфері «Банківської справи».

Перспективи подалыших розвідок у цьому напрямі. У перспективі передбачено розробити методичні рекомендації щодо організації освітньонаукового процесу професійної підготовки майбутніх економістів банківської справи з компетентностями для підприємницької діяльності із застосуванням дистанційних форм навчання.

\section{Jimepamypa}

1. Енциклопедія державного управління: у 8 т. / наук.-ред. колегія: Ю.В. Ковбасюк (голова) та ін. Київ: НАДУ, 2011. Т. 2: Методологія державного управління / наук.-ред. колегія: Ю.П. Сурмін (співголова), П.І. Надолішній (співголова) та ін. 2011. 692 с.

2. Титова Н.M. Теоретико-методичні основи психолого-педагогічної підготовки майбутніх педагогів професійного навчання: монографія. Київ: НПУ імені М.П. Драгоманова, 2018. 351 с.

3. Гальчинський А.С., Геєць В.М., Кінах А.К., Семиноженко В.П. Інноваційна стратегія українських реформ. Київ: Знання України, 2002. 336 с.

4. Мультимодусні засади післядипломної освіти для сталого розвитку: колективна монографія / за заг. редакцією Н.М.Рідей, В.П. Сергієнко. Вид-во НПУ імені М.П. Драгоманова, 2017. 634 с.

5. Національний класифікатор України: класифікатор професій. ДК 003: 2010. Київ: Держспоживстандарт України [Електронний ресурс]. Верховна Рада України. Законодавство Украӥни. URL: https://zakon.rada.gov.ua/rada/show/va 327609-10 (дата звернення: 10.08.2020).

6. Національний класифікатор України: класифікація видів економічної діяльності. ДК 009: 2010. Київ: Держспоживстандарт України [Електронний ресурс]. Верховна Рада України. Законодавство України. URL: https://zakon.rada. gov.ua/rada/show/vb457609-10\#Text (дата звернення: 10.08.2020).

7. Управління системами післядипломної освіти для сталого розвитку: колективна монографія / за заг. редакцією Рідей Н.М. Вид-во НПУ імені М.П. Драгоманова, 2019. 691 с.

8. Ісаєнко В.М., Рідей Н.М., Навроцька Д.В., Богуцький Ю.П., Уліщенко А.Б. Синергетична педагогіка: навчально-методичний посібник. видання 2-ге доповнене, перероблене. Вид-во «ОЛДІ-ПЛЮС», 2019. 416 с. 
9. Економічна безпека держави: сутність та напрями формування: монографія / за ред. д-ра екон. наук, проф. Л. С. Шевченко. Харків: Право, 2009. $312 \mathrm{c}$.

10. Соціальна економіка: навчальний посібник / кол. авт. О.О.Бєляєв, М.І. Диба, В.І.Кириленко, О.М.Комяков, О.В.Сінельник. Київ: КНЕУ, 2005. 244c.

11. Економіка підприємства: навчальний посібник / уклад. Н. В. Романченко, Т. В. Кожемякіна, К.В. Пічик. Київ: НаУКМА, 2018. 343 с.

12. Банківські операції: підручник / за ред. д.е.н., проф. О.В. Дзюблюка. Тернопіль: Вид-во ТНЕУ «Економічна думка», 2009. 696 с.

\section{References}

1. Surmin, Yu.P. (Ed.) (2011). Metodolohiia derzhavnoho upravlinnia. T. 2. In Kovbasiuk, Yu.V. (Ed.). (2011). Entsyklopediia derzhavnoho upravlinnia: 8 t.

2. Tytova, N.M. (2018). Teoretyko-metodychni osnovy psykholohopedahohichnoi pidhotovky maibutnikh pedahohiv profesiinoho navchannia.

3. Halchynskyi, A.S., Heiets, V.M., Kinakh, A.K., Semynozhenko, V.P. (2002). Innovatsiina stratehiia ukrainskykh reform.

4. Ridei, N.M., Serhiienko, V.P. (Ed.). (2017). Multymodusni zasady pisliadyplomnoi osvity dlia staloho rozvytku.

5. Natsionalnyi klasyfikator Ukrainy: klasyfikator profesii. DK 003: 2010. Kyiv: Derzhspozhyvstandart Ukrainy. Retrieved from https://zakon.rada.gov.ua/rada/show/va 327609-10.

6. Natsionalnyi klasyfikator Ukrainy: klasyfikatsiia vydiv ekonomichnoi diialnosti. DK 009: 2010. Retrieved from https://zakon.rada. gov.ua/rada/show/vb457609-10\#Text.

7. Ridei, N.M. (Ed.). (2019). Upravlinnia systemamy pisliadyplomnoi osvity dlia staloho rozvytku.

8. Isaienko, V.M., Ridei, N.M., Navrotska, D.V., Bohutskyi, Yu.P., \& Ulishchenko, A.B. (2019). Synerhetychna pedahohika.

9. Shevchenko, L.S. (Ed.) (2009) Ekonomichna bezpeka derzhavy: sutnist ta napriamy formuvannia.

10. Bieliaiev, O.O., Dyba, M.I. , Kyrylenko, V.I., Komiakov, O.M., \& Sinelnyk, O.V. (2005). Sotsialna ekonomika.

11. Romanchenko, N.V., Kozhemiakina, T.V., \&Pichyk, K.V. (2018). Ekonomika pidpryiemstva: navchalnyi posibnyk.

12. Dziubliuka, O.V. (Ed.) (2009). Bankivski operatsii. 